\title{
PERBANDINGAN ANTARA MODEL BLOK 3D DENGAN ORDINARY KRIGING DAN MODEL 2D DENGAN POLYGONAL UNTUK ESTIMASI SUMBERDAYA TIMAH ALUVIAL DI PULAU BANGKA
}

\author{
Olga Padmasari Anggraini ${ }^{1}$, Mohamad Nur Heriawan ${ }^{2}$, Arie Naftali Hawu Hede ${ }^{2}$ \\ ${ }^{1}$ Program Studi Sarjana Teknik Pertambangan, Fakultas Teknik Pertambangan dan \\ Perminyakan, Institut Teknologi Bandung \\ ${ }^{2}$ Kelompok Keahlian Eksplorasi Sumberdaya Bumi, Fakultas Teknik Pertambangan dan \\ Perminyakan, Institut Teknologi Bandung \\ Kontak e-mail: olgapadmasarianggraini@gmail.com
}

\begin{abstract}
Abstrak
Endapan timah aluvial di Blok I dengan luas sekitar 40 Ha di Pulau Bangka bagian urata merupakan lahan bekas tambang rakyat yang litologinya didominasi oleh tanah bekas (tailing), sisa endapan timah aluvial, dan batuan dasar (kong). Sebaran data secara spasial dan secara statistik dianalisis untuk menguji perilaku data pada setiap periode pemboran (1970-an, 1980-an, dan 2010-an). Pemodelan geologi secara 3D dilakukan dengan perangkat lunak Datamine Studio 3 berdasarkan data pemboran yang selanjutnya dilakukan estimasi kadar dengan metode Ordinary Kriging (OK). Ukuran cell dari proto model 3D yang digunakan adalah $10 \mathrm{~m} \times 10 \mathrm{~m} \times 1 \mathrm{~m}$. Untuk estimasi dengan metode OK, maka dilakukan analisis variogram omnidirectional $3 D$ untuk mendapatkan parameter geostatistik seperti nugget variance, sill, dan range dengan fitting model Spherical. Berdasarkan estimasi dengan metode OK didapatkan sumberdaya terukur timah aluvial sebesar 69 ribu $\mathrm{m}^{3}$ dengan kadar rata-rata $8 \mathrm{~kg} / \mathrm{m}^{3}$. Sebagai pembanding, dilakukan pemodelan sumberdaya secara $2 D$ dengan metode Polygonal menggunakan bantuan software AutoCAD 2019 (free trial). Estimasi sumberdaya terukur yang didapatkan berupa bijih timah sebesar 96 ribu $\mathrm{m}^{3}$ dengan kadar rata-rata $13.61 \mathrm{~kg} / \mathrm{m}^{3}$.
\end{abstract}

Kata kunci: potensi awal, timah aluvial, Ordinary Kriging, Polygonal, estimasi sumberdaya

\section{PENDAHULUAN}

\subsection{Latar Belakang}

Negara Kesatuan Republik Indonesia memiliki kekayaan alam yang melimpah, yang sudah selayaknya dimanfaatkan sebesar-besarnya bagi kemakmuran rakyat Indonesia.

Dalam usaha untuk memanfaatkan komoditas ini sebesar-besarnya harus disokong dengan kegiatan pertambangan yang memadai. Pengelolaan oleh penanam modal disertai dengan pembuatan regulasi di bidang pertambangan oleh pemerintah dilakukan untuk menjamin terlaksananya kegiatan pertambangan yang memadai.

Dengan dibentuknya sistem pengelolaan dan pengawasan kegiatan pertambangan oleh negara, tidak menutup kemungkinan berkembangnya kegiatan tambang tanpa izin (PETI) yang dilakukan oleh masyarakat setempat. Kegiatan PETI ini sangat merugikan baik bagi perusahaan yang memegang Izin Usaha Pertambangan (IUP) maupun negara.

Selain itu, hal ini juga sangat merugikan bagi banyak pihak karena umumnya kegiatan pertambangan mandiri ini tidak mengikuti kaidah good mining practice. Terlebih setelah ditinggalkan, tidak diketahui berapa jumlah sumberdaya yang masih tersisa. Maka dari itu, untuk dapat mengelola kekayaan ini dengan lebih optimal, langkah awal yang perlu dilakukan adalah inventarisasi jumlah 
sumberdaya agar dapat diukur potensi ekonominya bagi perusahaan maupun negara.

\subsection{Tujuan Penelitian}

Tujuan dari penelitian ini adalah:

1. Melakukan uji konsistensi antar data kadar lubang bor berdasarkan periode dilakukannya pemboran di daerah Blok I.

2. Melakukan pemodelan blok 3D dan pemodelan 2D serta menentukan hasil estimasi potensi volume dan kadar total dari sumberdaya timah alluvial di daerah penelitian dengan metode Ordinary Kriging dan membandingkan hasilnya dengan metode Polygonal.

3. Melakukan estimasi kehilangan sumberdaya timah akibat adanya penambangan tanpa izin berdasarkan analisis dengan hasil foto udara.

\subsection{Batasan Masalah}

Adapun batasan masalah dalam penelitian ini adalah:

1. Daerah penelitian berlokasi di Blok I yang terletak di bagian utara Pulau Bangka.

2. Data penelitian yang digunakan merupakan data collar dan assay pemboran yang terdiri dari 54 lubang bor.

3. Estimasi sumberdaya dilakukan dengan metode estimasi Ordinary Kriging dan Polygonal.

4. Perkiraan luasan daerah bekas penambangan tanpa izin dilakukan menggunakan foto udara dengan waktu pemotretan sekitar bulan Januari 2018.

\section{TINJAUAN UMUM}

\subsection{Lokasi dan Ketersampaian Daerah}

Blok 1 terletak di bagian utara Pulau Bangka. Untuk menuju lokasi penelitian diperlukan waktu sekitar 1 jam 10 menit penerbangan dari Bandar Udara Hussein
Sastranegara, Bandung menuju Bandar Udara Depati Amir, Pangkalpinang. Untuk mencapai lokasi diperlukan waktu sekitar 1 jam dengan menggunakan mobil. Peta lokasi daerah penelitian ditunjukkan pada Gambar 2.1.

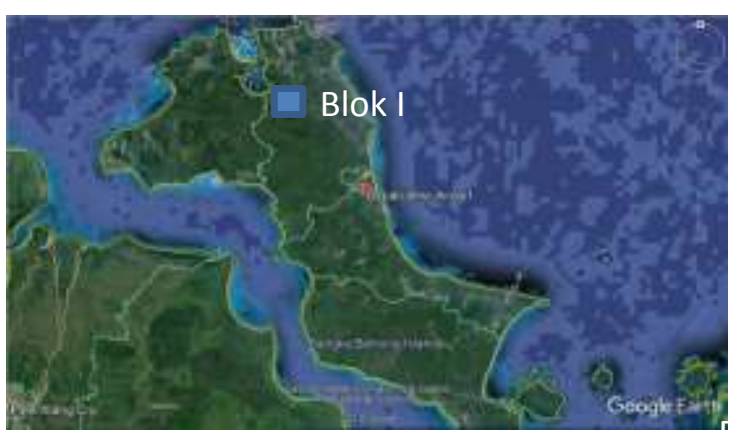

Gambar 2.1 Lokasi Penelitian di Pulau Bangka (Google, 2018).

\subsection{Geologi Regional Daerah Penelitian 2.2.1 Geomorfologi Regional}

Pulau Bangka (Bangka Island) merupakan salah satu pulau yang berada di Paparan Sunda dengan total luasnya mencapai $11.340 \mathrm{~km}^{2}$ (van Bemmelen, 1949). Menurut van Bemmelen (1949), Pulau Bangka ini termasuk ke dalam Sabuk Timah (Tin Belt) Pulau Bangka dan Belitung ini adalah bagian dari barisan pegunungan yang kemudian tenggelam karena kenaikan muka air laut pada zaman quarter akhir dan menyisakan sebagian puncaknya.

\subsubsection{Stratigrafi Regional}

Menurut Djamal \& Mangga (1994) pada peta geologi lembar Bangka Utara dan Margono, dkk. (1995) pada peta geologi lembar Bangka Selatan, stratigrafi Pulau Bangka dari tua ke muda tersusun atas beberapa formasi, antara lain Kompleks Malihan Pemali (CPp), Diabas Penyabung (PTrd), Formasi Tanjunggenting (Trt), Granit Klabat (TrJkg), Formasi Ranggam (TQr), Aluvium (Qa), Endapan Rawa (Qak), dan Pasir Kuarsa (Qs). 


\section{DASAR TEORI}

\subsection{Statistik}

\subsubsection{Statistik Univarian}

Statistik univarian merupakan metode statistik yang digunakan untuk menggambarkan distribusi dari peubahpeubah tunggal dan dapat dimanfaatkan dalam menganalisis hubungan antar masing-masing data dari suatu populasi tanpa memperhatikan lokasi dari data-data tersebut. Berikut ini beberapa parameter statistik yang sering digunakan untk mendeskripsikan distribusi data:
a. $\operatorname{Mean}(\mu)$
b. Median
c. Max dan $\min$
d. Varians $\left(\sigma^{2}\right)$
e. Coefficient of variation
f. Skewness
g. Kurtosis

\subsubsection{Statistik Bivarian}

Statistik bivarian merupakan metode statistik yang digunakan untuk menganalisis hubungan antar 2 (dua) kumpulan data atau variabel populasi yang berbeda, tetapi terletak di lokasi yang sama.

\subsection{Geostatistik}

Geostatistik adalah metode yang digunakan untuk menganalisis data dari suatu populasi dengan mempertimbangkan lokasi dari data-data tersebut secara spasial. Dalam geostatistik, dapat disederhanakan seperti yang ditunjukkan pada persamaan $(3-1)$ dan $(3-2)$ berikut ini:

$$
\begin{aligned}
& \gamma(h)=\frac{\operatorname{Var}\left[z\left(x_{i}-z\left(x_{i}+h\right)\right]\right.}{2}(3-1) \\
& \gamma(h)=\frac{\sum_{i=1}^{N}\left[z\left(x_{i}\right)-z\left(x_{i}+h\right)\right]^{2}}{2 N(h)}(3-2)
\end{aligned}
$$

Untuk jarak data yang tidak beraturan, maka diperlukan toleransi untuk variabel jarak dan arah pasangan data. David (1977) menjelaskan istilah angle classes $\left(\Theta \pm \frac{\Theta}{2}\right)$ dan distance classes $(\mathrm{h} \pm \Delta \mathrm{h})$ sebagai toleransi untuk menghitung pasangan data dengan jarak antar data yang tidak teratur.
Distance classes dan angle classes dapat dilihat pada Gambar 3.1.

Dari hasil plotting variogram eksperimental tersebut, kemudian dilakukan fitting dengan model variogram yang sudah ada sebagai berikut:

- Model Spherical

- Model Exponential

- Model Gaussian

Perbandingan model variogram spherical, exponential, dan gaussian dapat dilihat pada Gambar 3.2.

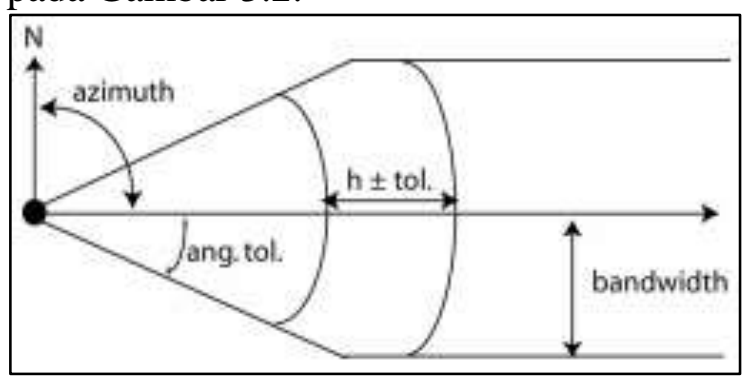

Gambar 3.1 Distance Classes dan Angle Classes (Bohling, 2005).

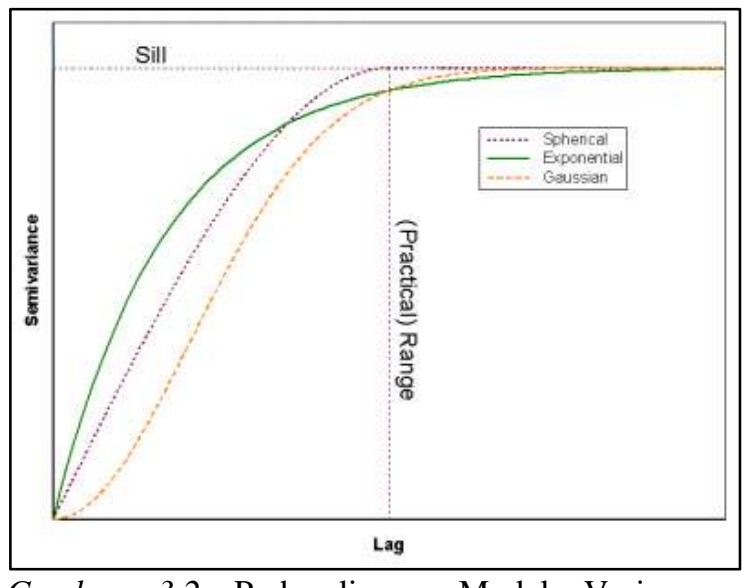

Gambar 3.2 Perbandingan Model Variogram (Bohling, 2005).

Model variogram yang digunakan dalam dunia pertambangan umumnya adalah model Spherical. Dari hasil fitting tersebut, kemudian akan didapat beberapa parameter penting yang akan digunakan untuk melakukan estimasi. Parameter tersebut adalah nilai sill $(\mathrm{C})$, nugget variance $\left(\mathrm{C}_{0}\right)$, dan range (a). Dimana definisi dari masing-masing parameter tersebut adalah sebagai berikut: sill menunjukkan nilai variansi dari suatu populasi, nugget 
variance merupakan nilai variogram saat $\mathrm{h}=0$ dan memiliki nilai tidak nol, range merupakan jarak pengaruh antar data.

Contoh variogram eksperimental dan model variogram dapat dilihat pada Gambar III.4.

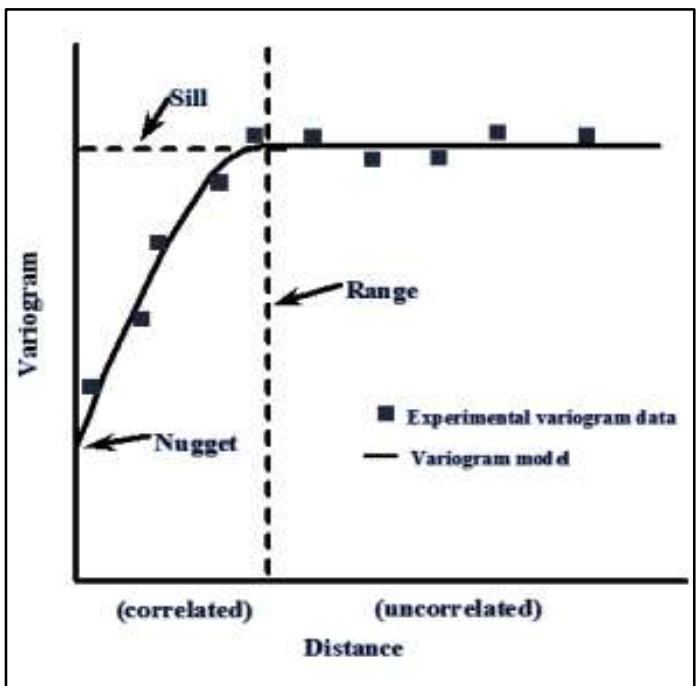

Gambar 3.3 Variogram Eksperimental dan Model Variogram beserta Komponen-komponennya.

\subsection{Metode Kriging}

Metode kriging adalah salah satu metode geostatistik yang banyak digunakan untuk mengestimasi nilai dari sebuah titik atau blok sebagai kombinasi linear dari nilai observasi yang terdapat di sekitar titik atau blok yang akan diestimasi. Dalam metode kriging, terdapat beberapa asumsi yang digunakan, yaitu variabel regional memiliki nilai $\mathrm{Z}\left(\mathrm{x}_{\mathrm{i}}\right)$ pada lokasi $\mathrm{x}_{\mathrm{i}}$ dan variabel regional memenuhi kondisi stasioner orde dua.

\subsection{Konstruksi Polygonal}

Salah satu metoda penaksiran umum yang digunakan dalam estimasi sumberdaya adalah metoda polygonal. Konstruksi poligon dapat dilihat pada Gambar 3.4.

Untuk perhitungan kadar total estimasi sumberdaya dengan metode polygonal, digunakan fungsi pembobotan aritmatika sederhana, yaitu pembobotan luasan atau volume.

\subsection{Genesa Endapan Timah Aluvial}

Endapan aluvial terbentuk akibat konsentrasi mineral berharga (mineral bijih) yang berasal dari perombakan batuan asal melalui beberapa mekanisme, antara lain: pelapukan (perombakan) batuan asal, perpindahan tempat (transportasi), pemisahan (sorting), pengkayaan (konsentrasi). Berdasarkan hal ini, endapan timah aluvial termasuk pada endapan sedimenter atau placer.

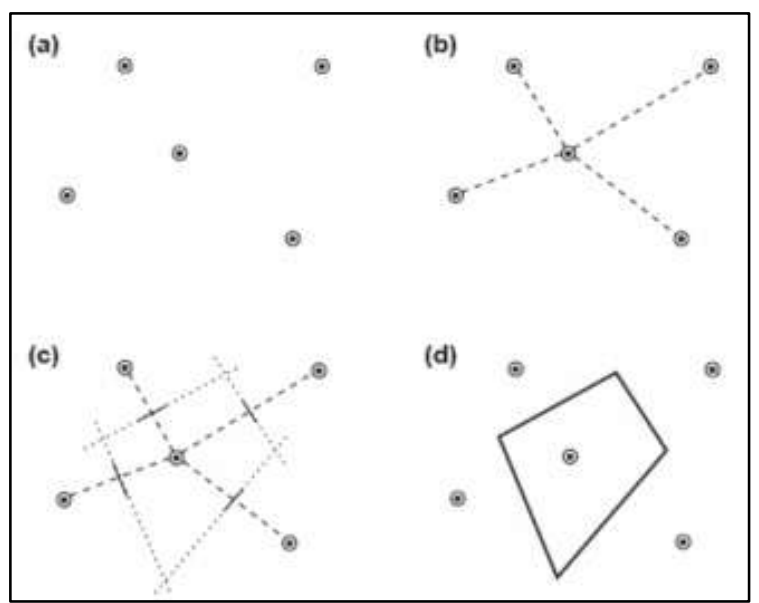

Gambar 3.4 Konstruksi Poligon.

Endapan aluvial merupakan konsentrasi mineral-mineral berat di lokasi-lokasi dimana terjadi suatu gangguan pada aliran (irregular flow) atau pengurangan energi, seperti: natural riffle, lubang pada dasar sungai atau air terjun, pada tubrukan arus sungai (pay streak), meander sungai, dll. Tipologi endapan timah placer terdiri dari endapan elluvial, coluvial, endapan kipas, endapan sungai, endapan rawa dan endapan pantai. Sebagian besar endapan timah yang ditemukan di jalur sabuk timah Indonesia adalah endapan sungai (alluvial).

\section{PENGOLAHAN DATA}

\subsection{Persiapan Basis Data}

Dalam melakukan pemodelan, baik untuk blok 3D maupun 2D, diperlukan suatu basis data yang diambil dari proses pengambilan conto yang dilakukan oleh salah satu perusahaan pertambangan di 
Pulau Bangka. Basis data ini nantinya berfungsi sebagai data input dalam proses estimasi sumberdaya timah yang dilakukan pada penelitian ini. Berdasarkan data-data yang telah diambil, basis data dapat dikelompokkan menjadi berbagai jenis data sesuai dengan definisi dan kegunaannya:

1. Data collar, merupakan data koordinat lokasi lubang bor, dimana conto diambil.

2. Data assay, merupakan data-data yang terdiri dari hasil pengambilan conto di setiap lubang bor dengan interval elevasi tertentu.

3. Peta topografi, merupakan peta kontur yang menunjukkan bentuk permukaan daerah penelitian.

\subsection{Uji Konsistensi Data}

\subsubsection{Analisis Distribusi Spasial Lubang Bor}

Analisis ini perlu dilakukan untuk mengetahui kondisi sebaran lubang bor. Kondisi yang dimaksud adalah tingkat percampuran lokasi lubang bor, semakin tinggi tingkatnya, semakin sulit untuk dikelompokkan berdasarkan waktu dan lokasi (mixed), tetapi semakin rendah tingkat percampurannya, maka lokasilokasi bor akan saling berkelompok (clustering) di sekitar lubang bor yang memiliki periode yang sama. Hal ini perlu diketahui, karena idealnya periode pemboran yang sangat berbeda sebaiknya tidak digabung untuk analisis geostatistik.

Gambaran distribusi spasial lubang bor hasil Validate and Desurvey yang dilakukan pada Datamine Studio 3 ditunjukkan pada Gambar 4.1, Gambar 4.2, dan Gambar 4.3.

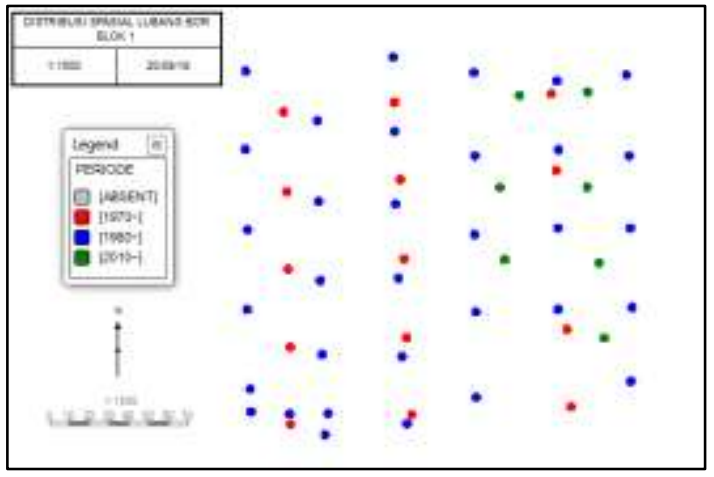

Gambar 4.1 Distribusi Spasial Lubang Bor Blok I.

Berdasarkan gambaran ini, dapat disimpulkan bahwa kondisi distribusi lubang bor bersifat mixed, sehingga pemodelan tidak dapat dilakukan secara terpisah (clustering) berdasarkan domain waktu.

\subsubsection{Analisis Distribusi Kumulatif Kadar Timah (Probability Plot)}

Analisis ini juga dilakukan untuk mengetahui kondisi persebaran data kadar bijih yang diambil tiap periode. Analisis ini dilakukan untuk memastikan data lubang bor dengan peridode pemboran berbeda yang secara spasial bersifat mixed dapat diolah secara gabungan.

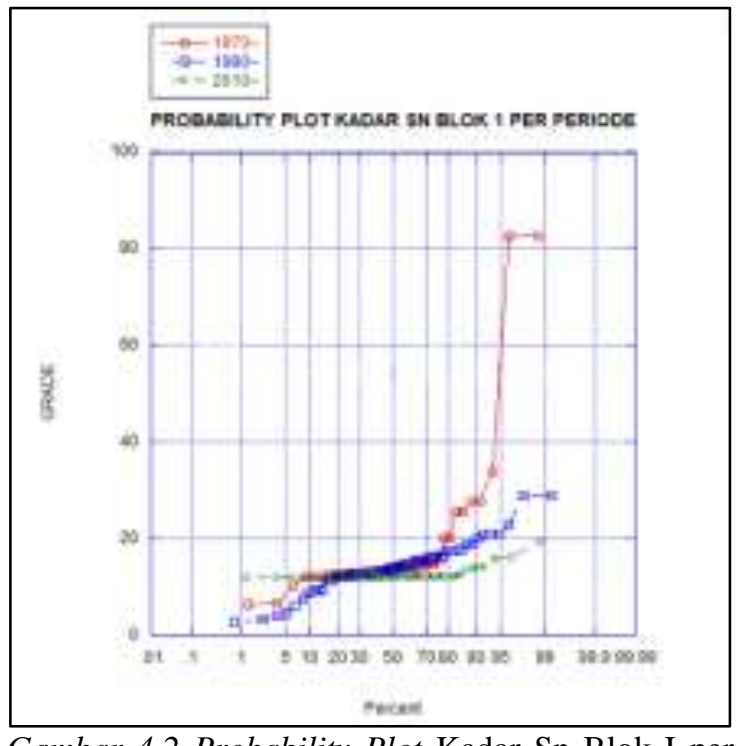

Gambar 4.2 Probability Plot Kadar Sn Blok I per Periode.

Berdasarkan grafik probability plot pada Gambar 4.4 data untuk setiap domain 
periode saling overlap. Hal ini menunjukkan bahwa data lubang bor yang sifatnya mixed ini dapat diolah secara gabungan.

Namun, apabila ditinjau lebih lanjut, terjadi kejanggalan pada Gambar 4.2 dimana terdapat data kadar Sn yang periode pengambilan datanya dengan periode lebih tua, terdistribusi lebih tinggi secara kumulatif, daripada yang periode lebih lama. Padahal, seharusnya apabila kegiatan tambang tanpa izin terjadi, sumberdaya semakin berkurang seiring dengan berjalannya waktu. Kejanggalan ini dapat disebabkan oleh lokasi pemboran yang kurang menyeluruh serta kondisi perlakuan terhadap conto yang kurang baik.

\subsection{Analisis Statistik Data Assay}

Analisis statistik ini dilakukan baik terhadap kadar Sn total yang berasal dari basis data assay maupun hasil estimasi dengan ordinary kriging. Analisis statistik untuk data assay dilakukan sebagai pembanding terhadap analisis statistik hasil estimasi. Statistik deskriptif dan histogram dapat ditampilkan pada Tabel 4.1 dan Gambar 4.3.

Tabel 4.1 Statistik Deskriptif Data Kadar Sn dari Assay Blok I.

\begin{tabular}{|c|c|}
\hline \multicolumn{2}{|c|}{$\begin{array}{l}\text { Statistik Deskriptif Data Kadar } \\
\text { Sn dari Assay Blok I }\end{array}$} \\
\hline Mean & 14,97 \\
\hline Median & 13,06 \\
\hline Standard Deviation & 9,13 \\
\hline Coefficient of Variation & 0,61 \\
\hline Kurtosis & 39,96 \\
\hline Skewness & 5,70 \\
\hline Range & 79,72 \\
\hline Minimum & 2,88 \\
\hline Maximum & 82,60 \\
\hline
\end{tabular}

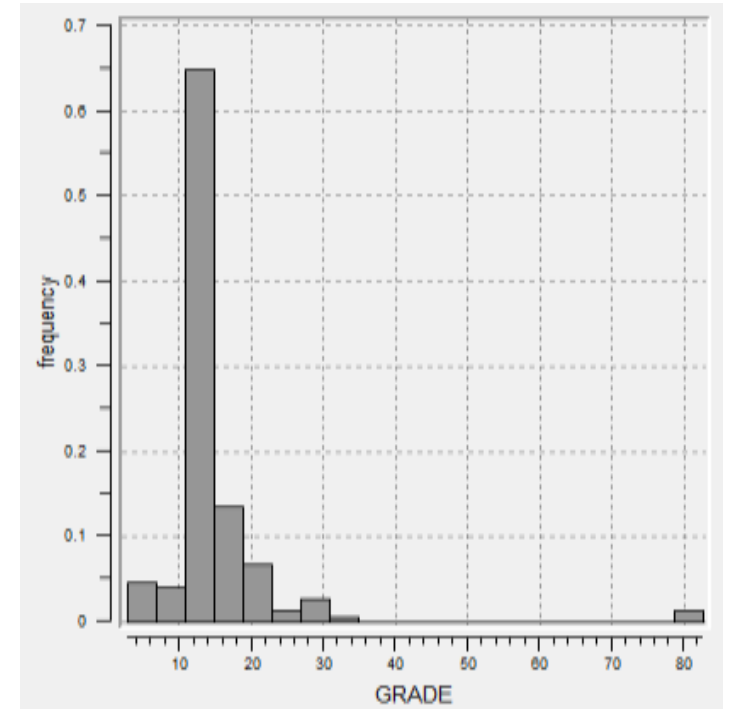

Gambar 4.3 Histogram Data Kadar Sn dari Assay Blok I.

\subsection{Pemodelan Geologi}

\subsubsection{Model Blok 3D}

Pemodelan 3D dilakukan dengan bantuan software Datamine Studio 3, dimana basis data collar dan assay, diinput ke dalam software. Sehingga setelah dilakukan pemodelan blok dapat menghasilkan tampilan seperti Gambar 4.4.

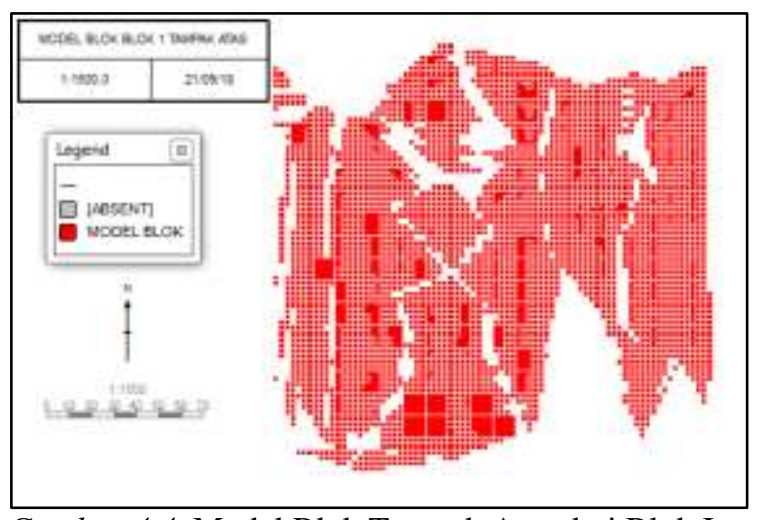

Gambar 4.4 Model Blok Tampak Atas dari Blok I.

\subsubsection{Model Polygonal 2D}

Dalam melakukan pemodelan 2D dengan metode Polygonal, diperlukan bantuan dari software AutoCAD 2019 (free trial). Namun sebelum pemodelan pada AutoCAD dilakukan, harus dilakukan plotting titik lubang bor pada software Surfer 11 . Setelah itu, hasil plotting akan diinput pada 
software AutoCAD. Tampilan dapat dilihat pada Gambar 4.5.

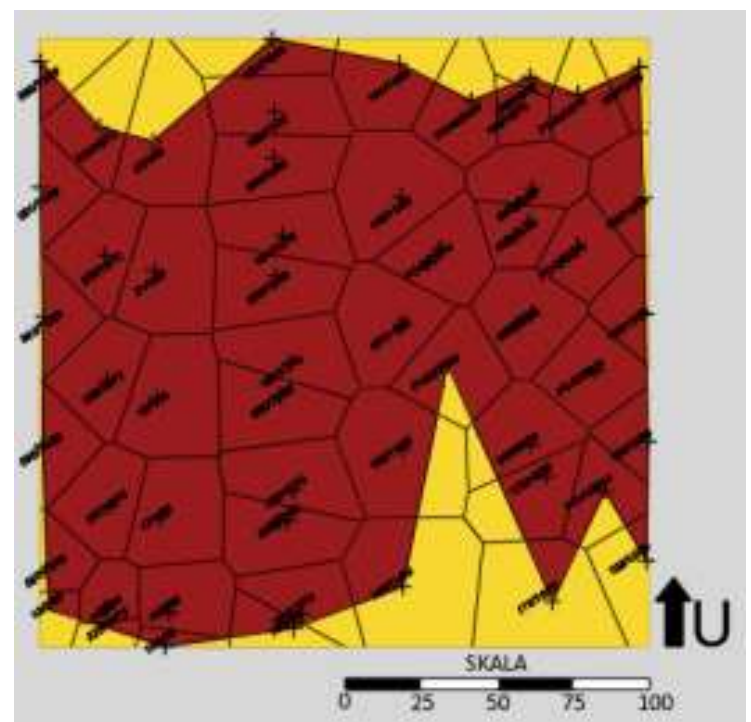

Gambar 4.5 Daerah Estimasi Polygonal Blok I.

\subsection{Analisis Geostatistik}

Dalam melakukan estimasi untuk model blok 3D dengan menggunakan metode Ordinary Kriging, selain analisis statistik, diperlukan juga analisis geostatistik yang mempertimbangkan kondisi spasial dari data-data tersebut. Variogram yang digunakan adalah 3D omnidirectional, hal ini dikarenakan variogram untuk arah horizontal menunjukkan ketidakteraturan extreme. Selain itu, dilihat juga dari geometri pemboran yang tidak teratur. Parameter input variogram yang digunakan diperlihatkan pada Tabel 4.2.

Tabel 4.2 Parameter Input Variogram 3D Omnidirectional.

\begin{tabular}{|c|c|c|c|c|c|c|}
\hline $\begin{array}{c}\text { Azimut } \\
h\end{array}$ & Dip & $\begin{array}{c}\text { Toleranc } \\
e\end{array}$ & $\begin{array}{c}\text { Bandwi } \\
\text { dth }(\mathrm{m})\end{array}$ & $\begin{array}{c}\text { Numbe } \\
\text { rof } \\
\text { Lags }\end{array}$ & $\begin{array}{c}\text { Lag } \\
\text { Separation }\end{array}$ & $\begin{array}{c}\text { Lag } \\
\text { Toleranc } \\
e\end{array}$ \\
\hline $0^{\circ}$ & $90^{\circ}$ & $90^{\circ}$ & 100 & 8 & 30 & 15 \\
\hline
\end{tabular}

Dari variogram omnidirectional ini, ditentukan nilai range, sill, dan nugget variance dari masing-masing data yang membentuk suatu model variogram yang sesuai dengan variogram experimental-nya melalui proses fitting. Gambar 4.6 menunjukkan variogram untuk kadar Sn total.

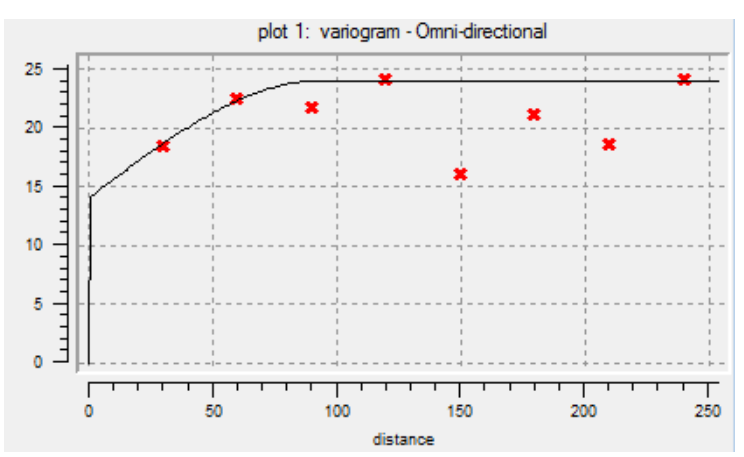

Gambar 4.6 Model Variogram 3D Omnidirectional untuk Kadar Sn Blok I.

Dari variogram tersebut, didapat parameter-parameter model variogram sebagaimana ditunjukkan pada Tabel 4.3.

Tabel 4.3 Parameter Model Variogram Tiga Dimensi Omnidirectional.

\begin{tabular}{|l|l|l|l|l|l|}
\hline \multirow{2}{*}{$\begin{array}{l}\text { Nugget } \\
\text { Variance }\end{array}$} & Model & \multirow{2}{*}{ Sariogram } & & \multicolumn{3}{|c|}{ Range (m) } \\
\cline { 4 - 6 } & & & Max & Med & Min \\
\hline 14 & Spherical & 10 & 90 & 90 & 90 \\
\hline
\end{tabular}

\section{ANALISIS DAN PEMBAHASAN}

\subsection{Estimasi Jumlah Sumberdaya}

Setelah kedua jenis model, baik model blok 3D maupun 2D sudah dibuat, dilakukan estimasi sumberdaya dengan parameter-parameter yang telah ditentukan pada sub-bab sebelumnya.

\subsubsection{Estimasi Sumberdaya dengan Ordinary Kriging}

Estimasi sumberdaya dilakukan dengan bantuan software Datamine Studio 3, dimana perintah Estimate dijalankan.

Data dari model blok estimasi ini dapat dilakukan analisis statistik univarian maupun histogramnya, untuk membandingkan keduanya dengan hasil analisis untuk data assay.

Berdasarkan statistik deskriptif yang dihasilkan oleh data hasil estimasi, terdapat suatu kejanggalan. Pada Blok I, dimana kadar Sn minimum daripada hasil estimasi lebih kecil jika dibandingkan dengan kadar Sn minimum pada data assay. Seharusnya, data minimum hasil estimasi lebih besar daripada data assay-nya, sedangkan untuk data maksimum hasil estimasi lebih kecil daripada data assay-nya. Hal ini 
kemungkinan terjadi, karena saat estimasi dengan Ordinary Kriging, IB (interburden) yang terdapat pada data lubang bor ikut terestimasi, sehingga menyebabkan kondisi underestimate.

Dan setelah model blok estimasi telah ditampilkan, dilakukan evaluasi untuk model blok tersebut yang akan menghasilkan jumlah volume dan kadar Sn total dari sumberdaya untuk setiap model blok. Rinciannya dapat dilihat pada Tabel 5.1 .

Tabel 5.1 Hasil Estimasi Volume, Tonase, dan Kadar Sn Total dengan Ordinary Kriging.

\begin{tabular}{|c|c|c|}
\hline $\begin{array}{c}\text { Volume } \\
\left(\mathrm{m}^{3}\right)\end{array}$ & $\begin{array}{c}\text { Kadar Sn Rata- } \\
\text { rata }\left(\mathrm{kg} / \mathrm{m}^{3}\right)\end{array}$ & $\begin{array}{c}\text { Tonase Sn } \\
\text { (ton) }\end{array}$ \\
\hline 69,700 & 8 & 558 \\
\hline
\end{tabular}

5.1.2 Estimasi Sumberdaya dengan Polygonal

Estimasi sumberdaya dilakukan dengan bantuan Microsoft Excel 2010. Volume dan kadar total dapat ditampilkan dalam Tabel 5.2 .

Tabel 5.2 Hasil Estimasi Volume, Tonase, dan Kadar Sn Total dengan Polygonal.

\begin{tabular}{|c|c|c|}
\hline $\begin{array}{c}\text { Volume } \\
\left(\mathrm{m}^{3}\right)\end{array}$ & $\begin{array}{c}\text { Kadar Sn } \\
\text { Total }\left(\mathrm{kg} / \mathrm{m}^{3}\right)\end{array}$ & $\begin{array}{c}\text { Tonase } \mathrm{Sn} \\
\text { (ton) }\end{array}$ \\
\hline 96.870 & 13,61 & 1.318 \\
\hline
\end{tabular}

\subsection{Analisis Perbandingan}

Perbandingan volume sumberdaya berdasarkan kedua metode dapat dilihat pada Gambar 5.1.

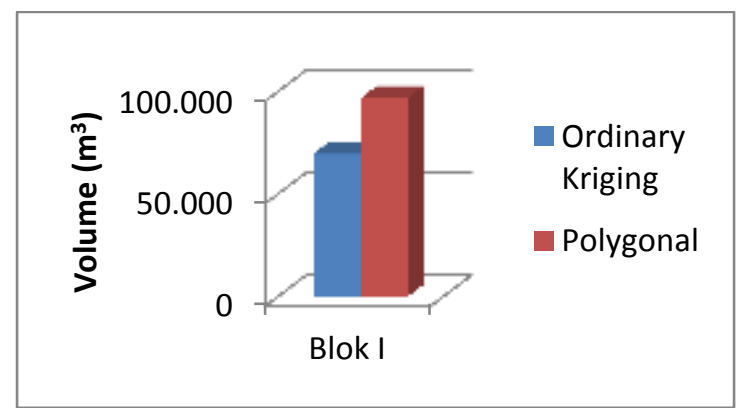

Gambar 5.1 Grafik Perbandingan Volume Ordinary Kriging dan Polygonal.

Berdasarkan grafik ini, dapat dikatakan bahwa volume yang dihasilkan oleh metode Polygonal lebih besar jumlahnya daripada metode Ordinary Kriging. Dengan selisih $27.170 \mathrm{~m}^{3}$.

Hal ini dapat disebabkan dari penggunaan metode Polygonal sendiri yang pada umumnya digunakan dalam estimasi sumberdaya endapan yang relatif homogen dan geometri sederhana, karena belum memperhitungkan tata letak (ruang) nilai data. Metode Polygonal lebih cocok digunakan pada kondisi endapan yang ketebalan bijihnya cenderung seragam, mendatar, dan menerus, sehingga karena daerah pengaruh yang besar, tidak akan menyebabkan overestimate, seperti yang terjadi pada objek penelitian.

Perbandingan volume sumberdaya berdasarkan kedua metode dapat dilihat pada Gambar 5.2.

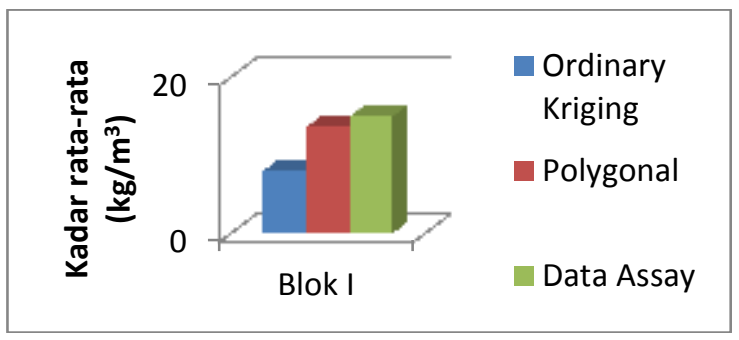

Gambar 5.2 Grafik Perbandingan Kadar Rata-rata Ordinary Kriging dan Polygonal.

Berdasarkan analisis untuk keseluruhan blok, kadar total Polygonal cenderung mendekati kadar rata-rata hasil analisis statistik data assay. Hal ini dapat disebabkan karena perhitungannya yang secara langsung menggunakan data kadar lubang bor dan mengasumsikan bahwa kadar Sn pada area di daerah pengaruhnya sama dengan kadar Sn lubang bor.

Sedangkan apabila dibandingkan dengan hasil estimasi metode Ordinary Kriging, kadar rata-rata assay dan estimasi Polygonal terlihat sangat tinggi. Hal ini disebabkan karena perhitungan menggunakan metode Ordinary Kriging melibatkan interpolasi nilai kadar di sepanjang jarak antar titik bor sesuai dengan jarak pengaruhnya. Sedangkan untuk estimasi menggunakan metode Polygonal, nilai kadar yang dihitung 
berlaku sama pada seluruh titik yang jaraknya paling dekat dengan titik bor (nearest point).

Perbandingan tonase $\mathrm{Sn}$ sumberdaya berdasarkan kedua metode dapat dilihat dalam grafik pada Gambar 5.3.

Apabila dibandingkan dengan hasil estimasi metode Ordinary Kriging, tonase $\mathrm{Sn}$ estimasi Polygonal terlihat sangat tinggi. Hal ini disebabkan karena perhitungan menggunakan metode Ordinary Kriging melibatkan interpolasi nilai kadar di sepanjang jarak antar titik bor sesuai dengan jarak pengaruhnya. Sedangkan untuk estimasi menggunakan metode Polygonal, nilai kadar yang dihitung berlaku sama pada seluruh titik yang jaraknya paling dekat dengan titik bor (nearest point).

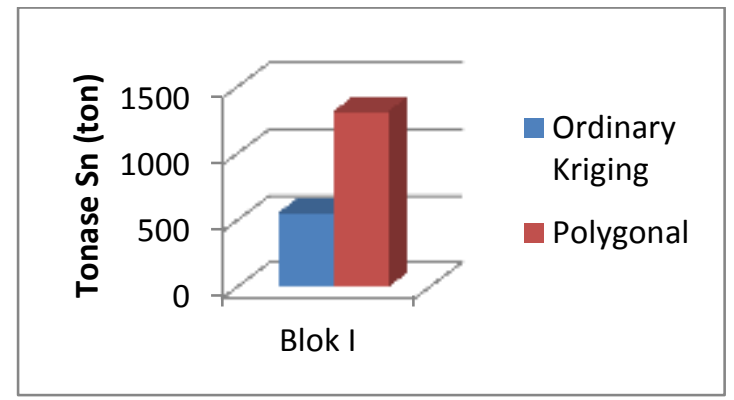

Gambar 5.3 Grafik Perbandingan Kadar Sn Ratarata Ordinary Kriging, Polygonal, dan Data Assay.

\subsection{Estimasi Potensi Pengurangan Sumberdaya}

Data foto udara daerah dibatasi menjadi seluas daerah penelitian yaitu berukuran $200 \times 200 \mathrm{~m}$, seperti ditunjukkan pada Gambar 5.4.

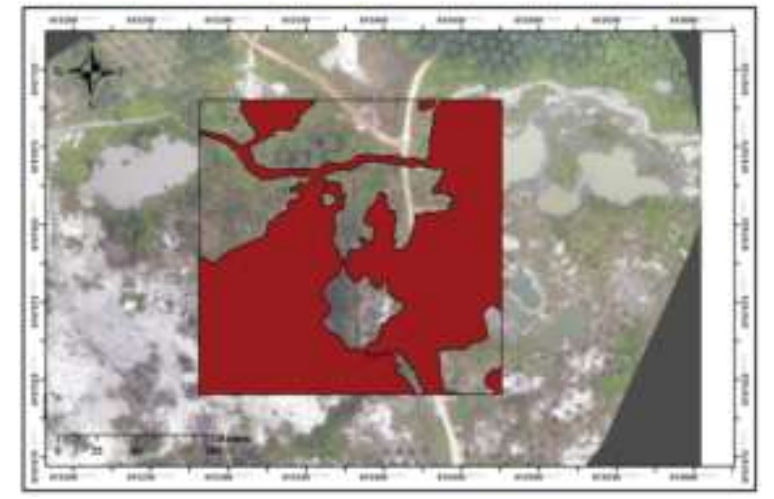

Gambar 5.4 Peta Foto Udara Pada Daerah Blok 1 tahun 2017

Dapat disimpulkan bahwa perkiraan luas wilayah kehilangan sumberdaya pada daerah penelitian antara lain $23.251 \mathrm{~m}^{2}$.

Daerah tailing dan kolong ini diasumsikan sebagai bijih yang telah ditambang tanpa izin, lalu ditimbun kembali dengan menggunakan tailing ataupun lubangnya terisi oleh air.

\section{KESIMPULAN DAN SARAN 6.1 Kesimpulan}

Dari hasil pembahasan di atas, dapat diambil kesimpulan sebagai berikut:

1. Berdasarkan hasil uji korelasi untuk kadar Sn, data lubang bor dengan periode pengeboran yang berbeda bersifat mixed secara spasial dan tidak dapat dimodelkan secara berkelompok (clustering). Akan tetapi, perbandingan pada probability plot dari data kadar Sn untuk setiap periode menunjukkan bahwa data saling overlap, sehingga dapat diolah secara tergabung.

2. Dari hasil estimasi sumberdaya timah aluvial yang dilakukan di daerah penelitian, terdapat perbedaan jumlah volume bijih dan kadar timah total, dimana hasil estimasi Polygonal lebih besar daripada Ordinary Kriging.

3. Kehilangan sumberdaya dari potensi awal hingga saat ini berdasarkan estimasi luasan dengan membandingkan foto udara tahun 2017 adalah sebesar $23.251 \mathrm{~m}^{2}$. 


\subsection{Saran}

Adapaun beberapa saran untuk kelanjutan penelitian ini adalah:

1. Eksplorasi perlu ditingkatkan menjadi tahap eksplorasi rinci agar dapat mengestimasi cadangan (terbukti).

2. Menambah lubang bor validasi untuk meningkatkan akurasi hasil estimasi cadangan (terbukti).

3. Diperlukan studi kelayakan untuk mengetahui apakah lahan bekas PETI tersebut masih layak tambang atau tidak.

\section{UCAPAN TERIMA KASIH}

Penulis mengucapkan terima kasih kepada Lembaga Penelitian dan Pengabdian pada Masyarakat, Institut Teknologi Bandung yang telah memfasilitasi penelitian ini melalui Riset KK B 2018 serta terima kasih juga kepada PT Timah Tbk. atas kerja samanya dalam penelitian ini yang telah memfasilitasi survei lapangan dan penggunaan dataset.

\section{DAFTAR PUSTAKA}

Amstrong, M., 1998, Basic Linear Geostatistics. New York: Springer.

Arrasyid, B.A., 2017, Pemodelan Tiga Dimensi Sumberdaya Timah Primer Menggunakan Metode Geostatistik di Blok Batubesi, Kabupaten Belitung Timur, Institut Teknologi Bandung, Bandung.

Badan Standarisasi Nasional, 2011. Pedoman Pelaporan, Sumberdaya, dan Cadangan Mineral, SNI 4726:2011.

Bohling, G, 2005, Introduction To Geostatistics and Variogram Analysis, C\&PE 940.

David, M., 1977, Geostatistical Ore Reserve Estimation, Elsevier Scientific Publishing Company, Amsterdam.

Koch, G. S. dan Link, R. F., 1970, Statistical Analysis of Geological Data, John Wiley \& Sons, New York.

Mangga, S. A. dan Djamal, B., 1994, Peta Geologi Lembar Bangka Utara,
Sumatera (1114) Sekala 1:250.000, Pusat Penelitian dan Pengembangan Geologi, Bandung.

Margono, U., Supandjono, RJB., dan Partoyo, E., 1995, Peta Geologi Lembar Bangka Selatan, Sumatera (1112, 1113, 1213) Sekala 1:250.000, Pusat Penelitian dan Pengembangan Geologi, Bandung.

Matheron, G. M., 1963, Principles of Geostatistics, Economy Geology.

Matheron, G. M., 1971, The Theory of Regionalized Variables and Its Applications, Ecole Nationale Superieure des Mines de Paris.

Ngadenin, N., Syaeful, H., Widana, K. S., Nurdin, M., 2014, Potensi Thorium dan Uranium di Kabupaten Bangka Barat, Pusat Pengembangan Bahan Galian Nuklir, Jakarta.

Osberger, R., 1965, Geologi Pulau Bangka. Tambang Timah Bangka.

Van Bemmelen, R.W., 1970, The Geology of Indonesia. Economic Geology Second Edition, Nijhoff, The Hague. 
